\title{
Pemaknaan Afiks Ter- dalam Bentuk Polimorfemis (?)
}

\author{
Ary Setyadi \\ Fakultas Ilmu Budaya, Universitas Diponegoro \\ mr.arysetyadi@gmail.com
}

\begin{abstract}
The ability to combine affixes with other morphemes in the form of polymorphism is interesting to study, because the ability to join with other factors influences the determination of various meanings. The determination of the meaning of an affixed lingual unit must start from the (existing) form and then to the meaning.

The study of the form of affixes polymorphic morphemes is based on the application of linguistic theory in the field of morphology, because the data problem is related to the complex morpheme shape. Sources of data depart, both from oral data sources and written data sources, so that existing data are primary and secondary.

The results of the data analysis show that the initial data is not data that is directly used as a basis for determining, but must first consider the sentence structure pattern (for the sake of structuring the logic elements and structuring grammatical elements).
\end{abstract}

Keywords: Affixes; shape; morpheme; polymorphism.

\section{Intisari}

Kemampuan daya gabung afiks ter- dengan morfem lain dalam bentuk polimorfemis menarik dikaji, sebab dari kemampuan bergabung dengan morfem lain berpengaruh atas penentuan bermacam makna. Penentuan makna satu satuan lingual berunsur afiks terharus bermula dari bentuk (yang ada) baru kemudian ke makna.

Pengkajian bentuk morfem polimorfemis berunsur afiks ter- bertolak pada penerapan teori linguistik bidang morfologi, sebab persoalan data berkait dengan bentuk morfem kompleks. Sumber data bertolak, baik dari sumber data lisan maupun sumber data tulis, sehingga data yang ada bersifat primer dan sekunder.

Hasil analisis data menampakkan bahwa data awal bukan merupakan data yang secara langsung dipakai sebagai bahan pijakan penentuan maka, tetapi harus terlebih dahulu perlu diperhatikan pola struktur kalimatnya (demi kebenaran penataan unsur logika dan penataan unsur tata bahasa).

Kata kunci; Afiks; bentuk; morfem; polimorfemis.

\section{Pendahuluan}

Upaya pengkajian pemaknaan afiks ter- dapat dikatakan menarik, sebab frekuensi penggunaan/kemunculan afiks ter- relatif (cukup) tinggi, sehingga mampu bergabung dengan morfem lain dalam membentuk morfem polimorfemis; tentu saja jika dibanding dengan afiks yang lain. Fakta semacam mudah dijumpai, baik dalam ragam lisan maupun dalam ragam tulis. Akibat dari kelebihan daya gabung dengan morfem -- sehingga mampu membentuk polimorfemis yang beragam--, maka akhirnya di setiap buku (sumber 
bacaan/referensi) yang menyoal morfologi bahasa Indonesia, dapat dipastikan membahas afiks ter-

Mengingat dengan begitu mudah menemukan sajian bahasan pemaknaan afiks terdalam beberapa buku yang menyoal morfologi bahasa Indonesia, terlebih mengingat bahwa penggunaan afiks ter- mengalami perkembangan, maka konsep dasar pemaknaannya sudah seharus dikaji ulang. Tujuan yang hendak dicapai dalam makalah ini adalah: mencoba memberi masukan (kepada pakar bahasa Indonesia) saat menyoal pemaknaan afiks ter-. Adapun dasar alasan atas tujuan yang hendak dicapai ini, bahwa fakta penggunaan afiks ter-sebagai pembentuk morfem polimorfemis relatif ada permasalahan.

Berdasarkan konsep dasar bahwa persoalan pemaknaan morfem (harus) bertolak dari 'bentuk (morfem) ke makna`, sehingga saat dipersoalkan pemaknaan afiks ter- perlu diperhatikan dengan seksama perihal bentuknya (akibat dari perkembangan penggunaan afiks ter- itu sendiri).

Pernyataan tujuan yang hendak dicapai di atas berlaku wajar, sebab berdasarkan buku yang menyoal morfologi bahasa Indonesia berdata masa lalu. Sedang apa yang disebut dengan data, tidak terlepas dari tuntutan perkembangan. Berdasarkan temuan data sebagaimana dalam beberapa buku bacaan, ternyata ditemukan data (baru), yang relatif belum dibahas dalam buku bacaan yang ada.

Bukti bahwa bentuk polimorfemis berunsur afiks ter- dari beberapa buku bacaan (yang ada) relatif masih berdata (masa lalu), dapat dilihat pada sajian Tinjauan Pustaka berikut ini. Adapun sumber bacaan yang melandasri sajian Tinjauan Pustaka bertolak dari, baik sumber bacaan yang dikategorikan sebagai buku lama (tata bahasa tradisional), maupun bertolak dari sumber bacaan yang yang dikategorikan sebagai buku baru (tata bahasa struktural).

Buku berjudul Tatabahasa Indonesia (Munaf, 1946: 153-155), keberadaan afiks ter- dibahas juga. Hasil bahasan bentuk polimorfemis hanya mecakup: 1. afiks terditambahkan pada nama sifat, contoh: terpandai, tertinggi, 2. pada kata nama benda yang tiada sejati dan pada kata benda yang sejati, contoh: terhormat, terpuji; terdasar, tertulang; dan 3. afiks ter- dapat ditambahkan pada kata nama sifat berulang, diberikan contoh: seakan-akan, termanja-manja.

Bertolak dari sajian bahasan tersebut, tampak jelas bahwa pembahasan kemampuan daya gabung afiks ter- dengan morfem lain dalam membentuk polimorfemis belum mendapat perhatian yang memadai. 
Mees dalam buku Tatabahasa Indonesia (1957: 86) meskipun telah menyoal afiks ter-, sajian bahasan hanya terbatas sudut makna. Yaitu dijelaskan bahwa afisk termembentuk elatif pada kata keadaan, ungkapan dengan paling (superlatif) dapat digantikan dengan ter-. Hanya saja yang sering dipakai adalah ungkapan seperti: terlalu, sangat, alangkah, bukan main, bukan buatan daripada afiks ter-.

Afiks ter- dalam buku Paramasastera (Ahmad, 1967: 126-129), afiks djelaskan dari segi maknanya; bukan dari bentuknya. Yaitu menyatakan: 1. pekerjaan telah selesai dengan tidak disengaja, 2. pekerjaan telah selesai dikerjakan (telah siap), 3. pekerjaan itu dapat atau sanggup dikerjakan oleh pelaku, dan 4. Sesuatu terjadi dengan tiba-tiba. Afiks terdapat juga menyatakan subjek mengenai atau menyentuh benda yang disebut kata dasarnya, dan menyatakan suatu taraf yang paling tinggi, sama artinya dengan paling. Dengan sajian tersebut, tampak jelas bahwa bentuk polimorfemis yang berunsur afiks terbelum mendapat perhatian secara mendalam.

Chaer dalam buku Penggunaan Imbuhan Bahasa Indonesia (1989: 99-106), keberadaan bahasan afiks ter- dapat dikatakan relatif luas. Yaitu bermula bahwa afiks termempunyai dua bentuk, yaitu berbentuk ter- dan te- (sebenar sebagai bentuk alomorf dari ter). Contoh: terangkat, terkejut; terasa, teramai. Persoalan kemampuan daya gabung hanya terbatas pada afiks ter- dapat bergabung dengan akhiran -kan dan $-i$, sehingga ditemukan bentuk ter-kan dan ter-i. Contoh: terkendalikan, terperika; ternodai, tertanami.

Bahasan bentuk polimorfemius yang berunsur afiks ter- dapat ditemukan dalam buku yang berjudul Tinjauan Kritis Teori Morfologi dan Sintaksis Bahasa Indonesia (Yohanes, 1991: 21-23). Hanya saja dalam buku tersebut, sajian bahasan afiks ter- terbatas pada penjelasan bahwa afiks ter- merupakan afiks yang asal usulnya dari bahasa Indonesia, dan dijelaskan bahwa afiks ter- tersebut dapat berfungsi sebagai pembentuk kelas kata sifat.

Soegijo dalam buku Morfologi Bahasa Indonesia (1989: 30), sajian bahasa hanya adanya penjelasan bahwa afiks ter- berperilaku sama dengan prefiksasi ber-dan per-, yaitu akan menimbulkan peristiwa-peristiwa kebahasaan. Contoh bentuk berunsur afiks ter-: terbawa, terdapat

Sajian bahasan afiks ter- dalam buku Morfofonemik Bahasa Indonesia (Sudarno, 1990: 108-108) relatif senada dengan pendapat Soegijo, sebab sajian bahasannya relatif sangat sederhana, yaitu dikatakan bahwa afiks ter- mempunyai alomorf te- dan tel-, dan berkemampuan bertemu dengan morfem bebas. Contoh: tepercaya, telanjur, terdorong. 
Sajian bahasan afiks ter- dapat dtemukan dalam buku Pengajaran Morfologi (Tarigan, 1985: 59-93). Bahasan dari buku tersebut, keberadaan afiks ter-, di samping mempunyai variasi bentuk ter- dan te- (sebagai bentuk alomorfnya); ternyata afiks terdapat digabung dengan kata dasar, dan dapat bergabung dengan afiks -kan dan $-i$. Contoh: terasa, tergambar; terseret-seratkan, tersurati.

Kridalaksana dalam buku Pembentukan Kata dalam Bahasa Indonesia (1996: 48; 61) juga membahas afiks ter-. Sajian bahasan yang tidak secara khusus membahas afisk ter-, sehingga persoalan bentuk polimorfemis berunsur berunsur ter- dapat dikatakan kurang mendalam. Inti bahasan dalam buku tersebut dikatakan, bahwa kehadiran afiks termempunyai banyak makna, dan mampu bergabung dengan kata verba dan kata ajektiva. Sajian bahasan atas makna afiks ter- dapat dikatakan sangat luas/mendalam.

Buku berjudul Ilmu Bahasa. Morfologi:Suatu Tinjauan Deskripsi (Ramlan, 1983: 55; 62; 86; 108-112) keberadaan afiks ter- dibicarakan secara mendalam. Sajian bahasan bermula dari pernyataan bahwa afiks ter- merupakan salah satu afiks (dalam bahasa Indonesia), afiks ter- dapat dijumpai dalam bentuk ulang, afiks ter- mengalami proses morofonemik, afiks ter- berbeda dengan afiks di-; dan berakhir pada bahasan makna afiks ter.

Sajian bahasan pada sumber bacaan tersebut memang relatif luas, hanya saja persoalan macam bentuk polimorfemis berunsur afiks ter- relatif belum/kurang, sebab sajian bahasan makna ter- terasa lebih dominan. Makna afiks ter- mencakup: 1. `asek perfektif, 2. ketidaksengajaa, 3. ketiba-tibaan, 4. mungkinan, dan 5. paling`.

Bertolak dari beberapa sajian bahasan yang sumber pada bacaan di atas, akhirnya dapat ajukan catatan: saat dilakukan pemaknaan afiks ter- perlu diperhatikan bagaimana perkembangan dan/atau penggunaan bentuk afiks ter- itu sendiri. Sebab berdasarkan temuan data, ternyata afiks ter- mengalami perkembangan penggunaannya.

\section{Metode Penelitian}

Mendasarkan pada tujuan yang hendak dicapai, sebagaimana telah disinggung di atas, maka dapat ditentukan macam bentuk polimorfemis afiks ter-diperlukan penerapan teori. Adapun teori yang dipergunakan demi capaian tujuan, adalah teori linguistik, yaitu bidang morfologi. Sebab bentuk polimorfemis merupakan data objek kajian bidang morfologi, yaitu sejalan dengan morfologi, "Mempelajari seluk-beluk bentuk kata serta fungsi perubahan-perubahan bentuk kata itu, baik fungsi gramatik maupun fungsi semantik." 
(Ramlan, 1983:17).

Bertolak dari pengertian morfologi tersebut, maka persoalan data harus bersyarat polimorfemis, sebab keberadaan afiks ter- dalam data merupakan (salah satu) bagian pembentuk bentuk polimorfemis. Adapun sumber data bertolak, baik dari sumber data lisan maupun sumber data tulis, sehingga keberadaan data bersifat primer dan/atau sekunder.

Tahap penelitian bentuk polimorfemis afiks ter-, sehubungan tujuan yang hendak dicapai, mendasarkan pada tiga tahapan strategis penelitian linguistik pada umumnya, yaitu dengan mendasarkan pada: 1. tahap penyediaan/pengumpulan data, 2. tahap klasifikasi dan analisis data, dan 3. tahap penyusunan/penulisan laporan (Sudaryanto, 1987: 46-49).

Tahap penyediaan/pengumpulan data bersumber, baik dari sumber data lisan maupun tulis, sehingga keberadaan kedua sumber data yang dimaksud saling melengkapi. Data dari sumber tulis diperoleh, baik dalam buku yang membicarakan morfologi bahasa Indonesia, maupun buku bacaan lainnya. Data dari sumber lisan, di samping berfungsi sebagai pengayaan data, sekaligus juga difungsikan sebagai tes kelayakan keberterimaan/kelaziman data dalam kegiatan bertutur.

Pelaksanaan penyediaan/pengumpulan data diimbangi dengan pencatatan data pada kartu data, sehingga ketersediaan kartu data relatif bersifat fungsional. Sebab, di samping sebagai cara penyimpanan data, sekaligus sebagai dasar pelaksanaan tahap yang kedua; tahap klasifikasi dan analisis data).

Tahap klasifikasi dan analisis data. Tahap klasifikasi mendasarkan pada bentuk data yang berunsur afiks ter-. Bagaimana fakta kemampuan afiks dalam bergabung dengan bentuk/morfem lain; baik bentuk polimorfemis yang hanya dibentuk oleh afiks ter- + kata, maupun gabungan afiks ter- dengan afiks lain + kata. Dengan demikian, dasar klasifikasian data bertolak pada struktur internal bentuk polimorfemis yang berunsur afiks ter-.

Analisis data mendasarkan pada penerapan teori linguistik bidang morfologi, yaitu dengan bertolak bentuk dari data yang berunsur afiks ter-. Sebab dari bentuk data yang ada dapat ditentukan kemampuan afiks dalam membentuk morfem yang polimorfemis. Dari bentuk yang ada, akhirnya dapat ditentukan macam bentuk morfem polimorfemis berunsur ter-, atau dengan kata lain, bahwa kemampuan daya gabung afiks ter- dengan morfem yang lain dapat ditentukan macam bentuknya.

Tahap terakhir, yaitu tahap penyusunan/penulisan laporan berlaku saat dilakukan analisis data, sebab saat dilakukan analisis data, saat itu pula secara langsung telah dilakukan penyusunan/penulisan. Dengan demikian, tahap terakhir ini berkait dengan 
kemampuan menulis dalam membuat laporan penelitian.

\section{Hasil dan Pembahasan}

Kajian macam morfem polimorfemis berunsur afiks ter- bermula dari pernyataan, bahwa apa yang disebut bahasa terdiri atas dua lapis, yaitu lapis bunyi (bentuk) dan lapis makna (Ramlan, 1985: 47). Keberadaan dua lapis yang ada bagaikan `dua gambar yangberbeda dalam satu mata uang`. Maksudnya meskipun berbeda, tetapi antarkeduanya merupakan satu kesatuan. Adanya lapis makna akibat adanya lapis bunyi (dalam ragam lisan)/lapis bentuk (dalam ragam tukus), atau sebaliknya. Dengan demikian, sebagaimana telah disebut di atas, sangat beralasan jika kajian makna afiks ter- dalam morfem polimorfemis seharus bermula dari lapis bunyi/bentuk dahulu baru ke makna; terlebih perkembangan pemakaian afiks ter- itu sendiri.

Kahadiran afiks ter- (yang merupakan salah satu macam afiks dalam bahasa Indonesia (Kridalaksana, 1996: 48)) dalam bentuk polimorfemis merupakan afiks tersendiri, pernyataan tersebut diperkuat oleh pendapat dari beberapa sumber bacaan, dan dijelaskan bahwa afiks ter- mempunyai alomor te- dan tel-; misalnya dalam bentuk polimorfemis teterka dan telanjur.

Kemampuan daya gabung afiks ter- dengan morfem lain, sebagaimana telah disebut di depan relatif (cukup) tinggi, sehingga mudah bergabung dengan morfem dalam membentuk morfem polimorfemis. Dengan demikian persoalan data tentang morfem polimorfemis berunsur afiks ter- begitu mudah ditemukan, baik dari sumber data ragam lisan maupun dari sumber data ragam tulis.

Berdasarkan hasil klasifikasi atas temuan data, akhirnya dapat ditemukan macam bentuk polimorfemis berunsur afiks ter- sebagai akibat kemampuan bergabung dengan morfem lain. Adapun hasil analisis data morfem polimorfemis berunsur afiks ter- dalam penelitian (awal) ini mencakup bentuk:

\section{Afika ter- + Morfem Dasar}

Bentuk morfem polimorfemis berunsur afiks ter- + morfem dasar mencakup: a. afiks ter- + kata sifat, b. afiks ter- + pokok kata, c. afiks ter- + kata kerja. Masing-masing bentuk yang ada dapat dijelaskan sebagai berikut.

\section{Afiks ter- + Kata Sifat}

Afiks ter- + kata sifat ini pada umumnya sering dipadankan/sinomimkan dengan mensubtitusi kata paling, sehingga bentuk morfen polimorfomis afiks ter- + kata sifat dapat 
diubah dengan kata paling. Contoh:

(1) Aminah memang gadis tercantik di desanya.

Kata cantik yang berafiks ter- secara pasti dapat dikatakan berkategori kata sifat, sebab mempunyai ciri sintaksis dapat didahului oleh kata sangat, sungguh, amat, ... sekali atau dapat dibuat dalam bentuk se- + R + -nya (Keraf, 1977: 28). Dengan demikian kata cantik (dalam kalimat) dapat berbentuk paling cantik, dan secantik-cantiknya.

Bukti bahwa data bersinomim dengan kata paling, maka data (1) dapat juga berbentuk (1a), sehingga dengan mudah memaknai afiks ter-adalah `paling`.

(1a) Aminah memang gadis paling cantik di desanya.

Kehadiran afiks ter-pada bentuk tercantik bukan merupakan afiks pembentuk kata kerja (pasif), tetapi sebagai sebagai afiks pembentuk kata sifat; sehingga data (1) tidak mungkin diubah menjadi (b).

(1b) *Aminah memang gadis dicantik di desanya.

Bertolak dari bentuk morfem data (1) relatif mungkin mudah dimaknai, tetapi bagaimana dengan beberapa kasus yang terjadi pada data berikut di bawah ini.

\section{Afiks ter- + Pokok Kata}

Bentuk morfem polimorfemis afiks ter- + kata kerja (diri) bukan merupakan afiks pembentuk kata (pasif) - sebagaimana kasus a --, sebab pokok kata tersebut yang diawali dengan afiks ter- merupakan kata sifat yang bersifat mempribadi (hanya berlaku pada diri pelaku yang bersangkutan). Contoh:

(2) Kakak terkesima ketika melihat bapak berseragam militer.

Berdasarkan hasil analisis, data (2) berbeda dengan data (1). Sebab jika data (1) dapat diubah menjadi (1a), sedang data (2) tidak mungkin diubah menjadi (2a); tetapi harus menjadi (2b).

(2a) *Kakak paling kesima ketika melihat bapak berseragam

militer. (2b) *Kakak dikesima ketika melihat bapak berseragam

militer.

Bertolak dari sajian analisis data (1) yang berbeda dengan data (2), maka tampak jelas bahwa apa yang disebut kata sifat sudah semestinya jika masih dapat dibedakan lebih rinci lagi. Bentuk morfem terkesima dikatakan berkategori kata sifat, sebab menampakkan ciri sebagaimana data (1); sehingga dapat diubah menjadi (2c).

(2c) Kakak sangat terkesima ketika melihat bapak berseragam militer.

Perlu dicatatkan di sini, bahwa kata kesima dapat digolongkan/berkategori sebagai prakategorial (Kridalaksama, atau pokok kata (Ramlan, 1983: 36) atau pangkal kata 
(Samsuri, 1985: 111), sehingga dapat disejajarkan dengan kata alir, juang, tari. Adapun apa yang disebut dengan pokok kata dapat dijelas sebagai satuan gramatikal yang terikat dalam tuturan (Ramlan, 1983: 87).

\section{Afiks ter- + Kata Kerja}

Bentuk morfem polimorfemis afiks ter- + kata kerja berlaku bertolak belakang dengan bentuk polimorfemis afiks ter- + kata sifat, sehingga data (3) tidak mungkin diubah menjadi (3a) dengan menggantikan kata paling sebagaimana data (1a); tetapi harus berbentuk (3b).

(3) Nama Ali sudah tertulis di daftar pemesanan.

(3a) *Nama Ali sudah paling tertulis di daftar pemesanan. (3b) Nama Ali sudah ditulis di daftar pemesanan.

Berdasarkan acuan maka apakah tertulis pada data (3) akan diberlakukan sama dengan data (3b)?, meskipun data (3) sering disejajarkan dengan (3b) yang dimaknai 'tidak disengaja` ataukah dimaknai ‘disengaja'?

\section{Afiks ter- Salah Kaprah Pola Struktur Kalimat}

Bentuk morfem polimorfemis berunsur ter- berlaku salah kaprah, berdasarkan data yang ada mencakup: a. salah berlogika, b. salah bertata bahasa. Dalam kalimat/tuturan selalu ada unsur logika dan unsur tata bahasa (Setyadi, 2010: 27). Masing-masing kasusus dapat dijelaskan sebagai berikut.

\section{Salah Berlogika`}

Pemaknaan afks ter- 'salah berlogika' dapat dibuktikan data (4), sehingga sebelum ditentukan maknanya; maka terlebih dahulu harus dikoreksi pola struktur kalimatnya. Contoh:

(4) Usah gelisah semua lampu sudah terpasang.

Data (4) seharus terlebih dahulu harus diubah menjadi (4a), sebab data tersebut salah berlogika. Mungkin tersedianya lampu tanpa ada pihak pelaku (yang memasang). Meskipun tipe kalimat (4) terkesan telah berlaku lazim bagi sebagian penutur bahasa Indonesia.

(4a) Usah gelisah semua lampu sudah dipasang.

Contoh selanjutanya, misalnya bagaimana dengan penggunaan bentuk terjamin, yang seharusnya berbentuk dijamin. 


\section{Salah Bertata Bahasa`}

Data yang berkait dengan `salah bertata bahasa`, misalnya dapat dilihat pada data berikut.

(5) Selama berhari-hari perahu itu terombang-ambing oleh ombak.

(6) Pelaksanaan program pemberdayaan terkait dengan program KB.

Data $(5,6)$ berlaku salah kaprah, khususnya dalam pola struktur kalimatnya, sebab seharus berbentuk $(5 \mathrm{a}, 6 \mathrm{a})$.

(5a) Selama berhari-hari perahu itu diombang-ambing oleh ombak.

(6a) Pelaksanaan program pemberdayaan berkait dengan program

$\mathrm{KB}$.

Data (5a, 6a) berbeda dengan data (7) yang tidak mungkin diubah menjadi (7a).

(7) Ibu Ida terbatuk-batuk karena asap

kompor. (7a) *Ibu Ida dibatuk-batuk karena

asap kompor.

Bertolak dari data $(5,6)$ yang seharus berbentuk $(5 a, 6 a)$ maka sudah semestinya jika saat dilakukan pemaknaan kata perlu diperhatikan asal-muasal bentuk berdasarkan pola struktur kalimat. Sebab jika pemaknaan afiks ter- langsung sebagaimana dataasli $(5,6)$, maka hasil pemaknaan pastilah salah.

Kasus pemaknaan afiks ter- sebagaimana data $(5,6)$ yang terlebih dahulu perlu diubah menjadi (5a, 6a) berbeda dengan kasus data (7) yang tidak mngkin diubah menjadi (7a). Dengan demikian, pemaknaan afiks ter- tidak serta-merta bertolak dari data awal.

\section{Afiks ter- + Kata Dasar + -kan/-i}

Kasus pemaknaan bentuk afiks ter- + kata dasar + -kan/-i berlaku sebagaimana kasus 'Salah Kaprah pola struktur Kalimat', contoh:

(8) Ternyata apa yang kita ingin termudahkan oleh Yang Maha Kuasa.

(9) Insha Allah semua kesalahan kita terampuni oleh Yang Maha

Kuasa. Keberadaan data $(8,9)$ seharus berbentuk $(8 \mathrm{a}, 9 \mathrm{a})$

(8a) Ternyata apa yang kita ingin dimudahkan oleh Yang Maha Esa.

(9a) Isha Allah semua kesalahan kita diampuni oleh Yang Maha Kuasa.

\section{Afiks ter- + Kata "Penghargaan"}

Kasus yang berkait dengan afiks ter- kata "penghargaan", misalnya dapat dilihat pada bentuk kata terhormat, terkasih, dan tersayang sebagaimana data berikut.

(10) Yang terhormat para peserta seminar....

(11) Yang terkasih anak-anak Yayasan .... 
(12) Anakku yang tersayang, ,...

Pemaknaan data $(10,11)$ tidak perlu kajian yang mendalam, sebab jika disandingkan dengan penggantian afiks $d i-$, maka perubahan sebagaimana data (10a, 11a) berlaku janggal

(10a) ? Yang dihormat para peserta seminar ....

(11a) ? Yang dikasih anak-anak Yayasan....

Perubahan data (10a) seharusnya (10b), tetapi perubahan data (11a) menjadi (11b) akan menjadi janggal.

(10b) Yang dihormati para peserta seminar ....

(11b) ? Yang dikasihi anak-anak Yayasan ...

Berbeda dengan perubahan (12) menjadi

(12a) (12a) Anakku yang disayang.

Data (12a) justru menampakkan adanya tuntutan kelengkapan kalimat, misalnya harus diubah menjadi:

(12b) Anakku yang disayang (oleh) ibu.

\section{Afiks ke- + ter- + Kata Dasar + -an}

Pemaknaan bentuk morfem polimorfemis dalam kasus ini dapat dilakukan dengan tahapan: 1. menentukan kata dasar, 2. menentukan bentuk dasar, 3. baru kemudian ke bentuk awal. Contoh:

(13) Kelakuan orang itu memang keterlaluan.

Bentuk morfem polimorfemis keterlaluan terdiri atas tahapan: 1. lalu (sebagai kata dasar), 2. ter- + lalu: terlalu (sebagai bentuk dasar), dan 3. terlalu + ke-an: keterlaluan, sehingga pemaknaan dari tahapan tersebut mengisyaratkan tahapan: 1. menentukan fungsi afiks ke-an dalam kaitan bergabung dengan bentuk dasar terlalu.

\section{Simpulan}

Berdasarkan sajian data dan analisis data di atas akhirnya dapat disimpulkan bahwa penentuan pemaknaan kata yang berunsur afiks, misalnya khususnya afiks ter-, harus berawal dari bentuk dahulu baru ke makna. Sebab persoalan bentuk yang ada pada bentuk morfem polimorfemis berunsur ter- relatif banyak permasalahan. Di setiap bentuk morfem polimorfemis berunsur afiks ter- berkait erat dengan konteks kalimat (yang mengacu pada kebenaran pola struktur kalimatnya).

Pemaknaan afiks ter- jika hanya mengandalkan data awal, terlepas dari bentuk yang berstruktur pola kalimat yang benar, maka hasil pemaknaan kurang/tidak benar. Sebab 
persoalan adanya tuturan yang "salah kaprah" dan dianggap wajar (bagi sebagian penutur bahasa Indonesia) perlu mendapat perhatian. Kenyataan semacam, khususnya pada penggunaan afiks ter-, berlaku wajar, sebab penggunaan afiks ter- akan terkoreksi oleh penggantian afiks lain akibat tuntutan perkembangan.

Akibat pemaknaan bentuk morfem polimorfemis berunsur afiks ter- mengalami tuntutan perkembangan, maka kasus semacam pantas diajadikan satu objek kajian tersendiri untuk kepentingan penentuan macam bentuk dan macam makna afiks ter-.

\section{Daftar Pustaka}

Ahmad, Sabaruddin. 1967. Paramasastera Indonesia. Medan: Saiful.

Chaer, Abdul. 1989. Penggunaan Imbuhan Bahasa Indonesia. Flores: Nusa Indah. Keraf, Gorys. 1977. Tata Bahasa Indonesia. Jakarta: Ende Flores.

Kridalaksana, Harimurti. 1996. Pembentukan Kata dalam Bahasa Indonesia. Jakarta: Gramedia Pustaka Utama.

Mees, CA. 1957. Tatabahasa Indonesia. Jakarta: JB

Wolters. Munaf, Husain. 1946. Tatabahasa Indonesia.

Jakarta: Fasco

Ramlan, M. 1983. Ilmu Bahasa Indonesia: Morfologi Suatu Tinjauan Deskriptif. Yogyakarta: CV. Karyono

Karyono.

1985. Ilmu Bahasa Indonesia: Sintaksis. Yogyakarta: CV.

Setyadi, Ary. 2010. "Bahasa Indonesia dalam Karya Ilmiah". Fak Ilmu Budaya Undip, Semarang.

Soegiyo. 1989. Morfologi Bahasa Indonesia. Semarang: IKIP Semarang Press.

Sudarno. 1990. Morfofonemik Bahasa Indonesia. Jakarta: Arikha Media Cipta.

Sudaryanto. 1987. Metode dan Aneka Teknik Analisis Bahasa: Penelitian Wahana Kebudayaan secara Linguistik. Yogyakarta: Gadjah Mada University Press.

Tarigan, Henry Guntur. 1985. Pengajaran Morfologi. Bandung: Angkasa.

Yohanes, Yan Sehandi. 1991. Tinjauan Kritis Teori Morfologi dan Sintaksis Bahasa Indonesia. Semarang: Nusa Indah. 